\title{
INTERPRETATION OF SUSCEPTIBILITY PHENOMENON OF SOME MANGO CULTIVARS TO INFESTATION BY MEALYBUG ICERYA SEYCHELLARUM (WESTWOD) (HEMIPTERA: MONOPHLEBIDAE)
}

\author{
EL- BADAWY, $\mathbf{S}$. S. \\ Plant Protection Research Institute, ARC, Dokki, Giza, Egypt
}

(Manuscript received 17 February 2014)

\begin{abstract}
A survey of scale insects and mealybugs on mango trees (Mangifera indica L.) (Anacardiaceae) were carried out in a private mango orchards located in El-Saff, Giza Governorate, during two successive years 2011-2012 for studying the role of mango leaf essential oil and their pure major constituents in interpretating the susceptibility phenomenon of five mango cultivar leaves to infestation with the white mealybug, Icerya seychellarum (Westwod) (Hemiptera: Monophlebidae).

The results indicated that, the mango trees were infested by 12 species of scale insects and mealybugs belonging to four families: Diaspididae, Coccidae, Monophlebidae and Pseudococcidae. From the monthly collection, the white mealybug, I. seychellarum was the most dangerous and abundant of the collected species. The selected five mango cultivars are not equally susceptible to $I$. seychellarum infestation. Fagrikalan mango trees cultivar (cv.) were heavily infested and severely damaged, while trees of Dabsha cv. are approximately complete free from I. seychellarum infestation. However, the susceptibility levels of mango cultivars to $I$. seychellarum could be arranged in descending order as follows: Fagrikalan >Alphonso-Naser > Baladi > Hendi >Dabsha. The essential oils of Fagrikalan and Dabsha mango cvs. leaves were determined by hydrodistillation and analyzed by GC-MS. A total of 38 components of the essential oil were identified. The insecticidal or repellent activities of some essential oils of the high susceptible Fagrikalan $\mathrm{cv}$. and the completely tolerable Dabsha cv. against $I$. seychellarum nymphs revealed that, the chemical composition of essential oils plays an important role in this concern. This hypothesis was confirmed by the results of toxicity and repellent activities of the pure major compounds limonene, $\beta$ caryophyllene, and a-pinene of Dabsha cv. and the attraction effect of the high quantity of $\beta$-ocimene in Fagrikalan cv. against $I$. seychellarum nymphs.
\end{abstract}

Keywords: Mangifera indica, Icerya. seychellarum, essential oils, susceptibility, repellent and insecticidal activities.

\section{INTRODUCTION}

Mango trees, (Mangifera indica L.) (Anacardiaceae) are considered of the most popular and economic fruit trees in Egypt. They occupy the third rank after citrus and grapes from the commercial point of view. Mango trees are liable to be 
infested with many serious pests during their growth stages including the phloem-feeding mealybug, Icerya seychellarum (Westwod) (Assem, 1990). The mealybug, I. seychellarum infests different parts of mango trees (leaves, branches and fruits) (Dreistadt et. al., 1994). Essential oils from different plant species possess ovicidal, larvicidal and repellent effects against various insect species and were regarded as environmentally compatible pesticides (Isman, 2000). Several studies conducted in different Egyptian localities showed that different mango cultivars express varying levels of tolerance to scale insects and mealybugs infestation in general and $I$. seychellarum in particular. (Monzer et. al., 2006 and Salem et. al., 2007). However, up to date, few studies determine the biological activities such as toxicity and repellency effects of essential oil of mango trees against scale insects and mealybugs. The present study was conducted to investigate the possible role of essential oil in susceptibility of five mango cultivars leaves (Fagrikalan, Baladi, Hendi, Alphonso-Naser and Dabsha) to $I$. seychellarum infestation and evaluate insecticidal and repellent effects of certain essential oils and their pure major compounds against the nymphs of mealybug, I. seychellarum.

\section{MATERIALS AND METHODS}

\section{Study site:}

This study was conducted in a private mango orchard (called Fisher orchards) located at El-Saff, Giza Governorate, Egypt. This 200-feddan orchard contains. 2000 trees of more than 10 mango cultivars, grow next to each other. Most trees were planted in 1935 and were more than $4 \mathrm{~m}$ high at the time of the study.

\section{Sampling of survey:}

Five local important mango cultivars were chosen (Fagrikalan, Baladi, Hendi, Alphonso-Naser and Dabsha). The cultivars type of the experimental trees were identified by taxonomy experts of Egyptian National Botanical Institute (Dokki, Giza, Egypt).The collection of samples was carried out monthly for two successive years from January 2011 to December 2012. Three representative trees from each cultivar were chosen at random and marked. Selected trees were similar in size, shape, height and vegetation. The marked trees and four trees adjacent to each of them were excluded from any chemical treatment applied to the rest of the orchard. A sample comprising 10 leaves was collected randomly from each of the four cardinal directions (East, West, North and South) of the middle crown parts from each of the three marked trees for each cultivar i.e. 120 leaves per sample ( 3 trees $\times 4$ directions $\times 10$ 
leaves). Leaves of each tree were packed separately in paper bags and transferred into the laboratory for carefully inspection in the same day.

\section{Identification of insects and population density:}

In the laboratory, scale insects and mealybugs were identified in department of scale insects and mealybugs. Population densities of $I$. seychellarum on Fagrikalan, Baladi, Hendi, Alphonso-Naser and Dabsha cultivar leaves were estimated on three trees for each cultivar. Total numbers of a live nymphs and adults on each leaf were counted and their total numbers for each cultivar on each inspection date were calculated.

\section{Chemical analysis:}

Leaves of Fagrikalan, and Dabsha cultivars were sampled using the same procedure described above. Leaves were carefully examined and insect damaged, old and infested leaves were removed. Healthy leaves were maintained at $-20^{\circ} \mathrm{C}$ until extraction. The pure compounds (limonene, $a$-pinene, $\beta$-caryophyllene, terpinolene and $\beta$-ocimene) were purchased from Sigma-Aldrich Chemical Co.

\section{Extraction of the essential oil:}

The essential oil was extracted from the fresh leaves of Fagrikalan and Dabsha cultivars (500g fresh weight of each sample in $500 \mathrm{ml}$ of distilled water) by hydrodistillation using a Clevenger type apparatus for $4 \mathrm{~h}$. The distilled was extracted with ether after saturation with sodium chloride. The ether extract was dehydrated over anhydrous sodium sulfate. Solvent was removed under reduced pressure at 20 ${ }^{\circ} \mathrm{C}$. The volatile constituents was packed in dark container and kept in refrigerator till analysis.

\section{Chemical analysis of essential oil:}

\section{Gas chromatographic-mass spectrometric (GC-MS) analysis:}

The prepared essential oil was subjected to GC / MS analysis using Shimadzu GC/MS-QP 5050A. Column: DB5, 30 m, 0.53 mm ID, $1.5 \mu \mathrm{m}$ film. Carrier gas: Helium (flow rate $1.2 \mathrm{ml} / \mathrm{min}$.). Ionization mode: (70 ev). The injection volume was $0.5 \mu \mathrm{L}$ (split ratio of $1: 100$ ), Temperature program: $50^{\circ} \mathrm{C}$ (static for $2 \mathrm{~min}$ ) with gradually increasing (a rate of $4^{\circ} \mathrm{C} / \mathrm{min}$ ) up to $200^{\circ} \mathrm{C}$ then $\left(10^{\circ} \mathrm{C} / \mathrm{min}\right.$ ) to $280^{\circ} \mathrm{C}$. The detector temperature was $290^{\circ} \mathrm{C}$, while, the injector temperature was $250^{\circ} \mathrm{C}$.

\section{Identification of the chemical constituents:}

Qualitative identification of the essential oil was achieved by library searched data base Willey 229 LIB as well as by comparing their retention indices and mass fragmentation patterns with those of the available references and with published data, (Adams, 2007). The percentage composition of components of the volatile was determined by computerized peak area measurements. 


\section{Toxicity bioassays}

A series of laboratory bioassays were conducted to determine the bioactivity of Dabsha and Fagrikalan leaf oil and their major constituents against $I$. seychellarum nymphs.

\section{1- Spray toxicity assay:}

The toxicity bioassay was conducted to evaluate toxicity of Dabsha and Fagrikalan leaf oil and their major constituents to $I$. seychellarum nymphs at three different concentrations (100, 1000, 10000 ppm). In spray toxicity assay, leaves containing nymphs were placed into plastic Petri dishes $(10 \mathrm{~cm}$ dia $\times 2 \mathrm{~cm} \mathrm{ht})$. After solvent evaporation (acetone), for each oil leaf and their major constituents, ten infested leaves (each bearing not less than $10 \mathrm{I}$. seychellarum nymphs) of Baladi mango cultivar were sprayed with each oil and their major constituents, then, kept at room temperature. Control insects were sprayed with acetone. Five replicates were used and the experiment was repeated for three times. Mortality of insects was assessed after $48 \mathrm{hrs}$.

\section{2- Contact toxicity assay (Thin Film Technique):}

This technique was used according to Pascual and Robledo. (1997). $1 \mathrm{ml}$ of different concentrations $(100,1000,10000$ ppm) of Dabsha and Fagrikalan leaf oil and their major constituents in acetone were sprayed from all sides to $9-\mathrm{cm}$ petri dishes and the solvent was allowed to evaporate at $25^{\circ} \mathrm{C}$ for $24 \mathrm{~h}$. For each concentration five replicates of ten mealybug nymphs, in addition to a control (solvent only) were used. Mortality records were taken after 48 hours. Number of dead nymphs were counted and converted to percent mortality for each oil and their major constituents.

\section{Repellency assay (Filter paper test):}

The repellency (or) attractiveness of Fagrikalan and Dabsha mango leaves, essential oil leaves and their major compounds against $I$. seychellarum nymphs was determined as described by (Wang et. al., 2009). The crude essential oil and the pure major compounds were diluted in acetone to three concentrations (100,1000, 10000 $\mathrm{ppm}$ ). Filter paper (6 $\mathrm{cm}$ in diameter) was cut in half and to small pieces. The first half small pieces were placed near the side of Petri dish and the other half pieces were placed on the opposite side of the dish to serve as control. $150 \mu \mathrm{L}$ of each concentration was applied separately to the first half of the filter paper as uniformly as possible with a micropipette. The other half (control) was treated with $150 \mu \mathrm{L}$ of absolute acetone. Both the treated half and the control half were then air dried to evaporate the solvent completely. I. seychellarum nymphs were collected from Baladi mango leaves before the experiment and were starved for $6 \mathrm{hrs}$. Ten nymphs were placed in the center of the dish, $4 \mathrm{~cm}$ away from both the treated half and the control 
half. Dish was covered and maintained at room temperature. After 24 hours, number of nymphs on the treated half and the control half was counted. Insects within $5 \mathrm{~mm}$ of the tested material were counted as being attracted to the source. Five replicates were used and the experiment was repeated for three times. The percent repellency of each Fagrikalan and Dabsha mango essential oil leaves and their major compounds was then calculated according to Thurston et. al. (1994) as follows:

$$
\mathrm{PR}(\%)=[(\mathrm{NC}-\mathrm{NT}) /(\mathrm{NC}+\mathrm{NT})] \times 100
$$

where: NC was the number of nymphs present in the negative control half, NT was the number of nymphs present in the treated half.

\section{Statistical analysis}

The population density of $I$. seychellarum on mango leaves were reduced to tree-specific means and these means were used in statistical analysis. Data of all experiments were evaluated statistically using ANOVA and means compared using Duncan's Multiple Range Test at $\mathrm{P}<0.05)$. All statistical analyses were done using the software package Costat. (Costat 2005).

\section{RESULTS AND DISCUSSION}

\section{Survey of scale insects and mealybugs}

The survey of scale insects and mealybugs infesting mango trees indicated that, mango trees were infested by 12 scale insects and mealybugs species: five species belonging to family Diaspididae, three species to family Coccidae, two species to families Monophlebidae and Pseudococcidae, (table 1). The highest abundant species was I. seychellarum $(81.93 \%)$ of the total collected species, followed by Lepidosaphes beckii (Newman) (9.77\%), then Kilifia acuminata (Signoret) (4.80\%) and Hemiberlesia lataniae (Signoret) (1.91\%). The less abundant species were Ceroplastes floridensis (Comstock) $(0.51 \%)$, Parlatoria oleae (Colvee) $(0.23 \%)$, Aulacaspis tubercularis (Newstead) (0.22\%), Aonidiella aurantii (Maskell) (0.19\%), Planococcus citri (Risso) (0.11\%), Pulvinaria vitis (Linnaeus) $(0.09 \%)$, Icerya aegyptiaca (Douglas) (0.10\%) and Planococcus ficus (Signoret) $(0.08 \%)$. According to these results, the population densities of the most serious and abundant species $I$. seychellarum were studied on leaves of five mango cultivars Fagrikalan, Baladi, Hendi, Alphonso-Naser and Dabsha in this assay.

\section{Infestation levels and population densities of $\boldsymbol{I}$. seychellarum:}

Population densities of the $I$. seychellarum on leaves of mango cultivars Fagrikalan, Baladi, Hendi, Alphonso-Naser and Dabsha at the sampling date are shown in fig. (1), fig. (2) and table (2). The highest mean number of $I$. seychellarum 
individuals per 10 leaves was found on Fagrikalan cultivar (546) and (525) in the two successive years 2011 and 2012, respectively, flowed by Alfanso-Naser (213) and (208) then Hendi (184) and (180) and the lastly Baladi (43) and (40). Dabsha leaves were approximately clear from $I$. seychellarum infestation. Accordingly, the order of susceptibility levels of mango cultiva8989rs to $I$. seychellarum could be arranged in descending order as follows: Fagrikalan (highly susceptible) > Alfanso-Naser > Hendi >Baladi>Dabsha (highly tolerable). The calculated infestation rates of $I$. seychellarum were relatively low in winter, spring and summer months, whereas, the high rates were recorded with autumn months in both years. The highest abundance was recorded during October month (24.52 and $32.76 \%$ ) and the lowest abundance was recorded during April (2.49 and $0.62 \%$ ) in the two successive years, respectively. The overall population densities were not similar among the two studied years, since, the population density of the first year 2011was higher than the second year 2012. This difference in $I$. seychellarum activity is possibly attributed to the variation of the chemical composition (quantitvlly and qualitivlly) of the mango leaves cultivars or weathering conditions. In this study, influences of the weathering conditions and resource availability could not explain the differences in the level of cultivar susceptibility to $I$. seychellarum because trees of all the studied cultivars grow next to each other in Fisher mango orchards. This was supported by Assem (1990) mentioned that neither temperature nor relative humidity showed any significant correlation with population density of $I$. seychellarum on ornamental plants, In contrary, AbdElrahman et. al., (2007), showed that, the difference in population density of $I$. seychellarum on mango trees is possibly attributed to the differences in the weathering conditions. El-Said (2006), reported that, the predation of Rodolia cardinalis (Muls.) on I. seychellarum had no influence in the level of infestation of mango trees.

Differences in susceptibility of various mango cultivars to scale insects had reported by several studies. Salem et. al., (2007) showed that, population densities of the I. seychellarum on leaves of Sultani, Baladi, Hendi, Ewaisi and Alphonso mango cultivars were significantly different. They concluded that, Alphonso was completely resistant, while Sultani was highly susceptible to $I$. seychellarum and the order of susceptibility of the studied mango cultivars to $I$. seychellarum could be arranged in descending order as follows: Sultani >Baladi>Hendi>Ewaisi>Alphonso and the levels of susceptibility of mango cvs. for the mealybug, I seychellarum depend on the combined action of leaf nutrients, inhibitors, leaf properties and secondary metabolites. On other hand, Monzer et. al., 2006 reported that, leaf nutrients, inhibitors and leaf properties cannot explain the completely resistant of 
Alphonso leaves to $I$. seychellarum infestation. They proved that, Alphonso leaves contain certain repellant or toxic secondary metabolites responsible for their resistance to $I$. seychellarum infestation. However, the preference of $I$. seychellarum to Fagrikalan leaves and avoidance of Dabsha leaves can be interpreted by presences of leaf secondary metabolites especially essential oils, which are the most important secondary metabolites. To achieve this assumption, the chemical constituents of essential oils from leaves of Fagrikalan and Dabsha mango cvs. were analyzed and laboratory bioassays were conducted on Fagrikalan and Dabsha cvs. essential oil leaves and its effective compounds against the nymphs of mealybug, I. seychellarum. This is the first study that examines the relation between the differences in susceptibility of different mango cultivars to $I$. seychellarum and mango essential oils and its constituents.

\section{Chemical analysis of constituents of oil.}

The chemical composition of the essential oils of leaves of Dabsha and Fagrikalan cultivars are presented in table (3). The oil analysis by GC and GC/MS of the essential oil revealed the presence of 38 peaks, approximately all peaks were identified and representing 97.92 and $93.20 \%$ of the essential oil of Dabsha and Fagrikalan cultivars, respectively. The oils of the two cultivars yields were $1.55 \%$ and $1.05 \%$, respectively. Monoterpenes and sesquiterpenes hydrocarbons were found to be the most abundant volatiles of the two mango cultivars. This sort of compounds has also been found to be volatile components of many mango cultivars (Pino et. al., 2005). These analyses also revealed that the major identified components in the leaves oil of Dabsha mango cv. were monoterpenes and sesquiterpenes. limonene $(15.30 \%)$, a-pinene $(14.39 \%)$, a-terpinolene $(7.70 \%)$, 3-carene $(5.26 \%)$, camphene (4.34\%) and eugenol (3.45\%) were the major monoterpenes and oxygenated monoterpenes, whereas, sesquiterpenes were $\beta$-caryophyllene $(9.16 \%)$, a-gurjunene $(5.10 \%)$ and humulene epoxide (1.45\%). The monoterpene $\beta$-ocimene $(36.80 \%)$ was the principal constituent in the leaves of Fagrikalan cv. whereas, the major identified components of sesquiterpenes and oxygenated sesquiterpenes were a-selinene $(7.34 \%), \beta$-selinene $(6.45 \%)$, $\beta$-elemene $(4.50 \%)$, a-caryophyllene $(1.70 \%)$ and $a-$ humulene (1.20\%). Our results were confirmed by Pino et. al., (2005), who showed that, the main compound classes of the essential oil of mango leaves were monoterpenes (e.g. $\beta$-pinene, a-pinene, limonene, a-terpinolene, myrcene, cis and trans-ocimene) and sesquiterpenes (e.g. $\beta$-caryophyllene, caryophyllene oxide, 3carene, a-gurjunene, humulene epoxide, $a$ and $\beta$-selinene). In other study, Engel and Tressel, (1983) found that, cultivars from Egypt (Alphonso and Baladi) had limonene as main constituent. 
Other compounds were also found in relative amounts, (Z)3-Hexenol is the main component (5.40\%) in Fagrikalan cultivar and very small amount in Dabsha cultivar $(0.10 \%)$, the main compounds of hydrocarbons in Dabsha and Fagrikalan mango cultivars were n-Decan $(1.20 \%),(1.39 \%)$ and Eicosane $(1.45 \%),(1.34 \%)$, respectively, two important fatty acids palmitic acid (1.23\%) (1.98\%) and oleic acid $(1.13 \%),(1.67 \%)$ were also found in both cultivars, respectively. The essential oil of Fagrikalan and Dabsha cultivars are characterized by the unusual presence of benzene derivatives (1,2,3,4-tetrahydro-1-naphthalene,1,2 dicarboxylic benzoic acid and 3methyl benzoic acid) these compounds were firstly isolated from Fagrikalan and Dabsha cultivars, however, these compounds does not seem to be widely distributed in the M. indica. table (3), also shows that there are important and appreciable differences between percentages of the leaf essential oil contents of the two cvs. Leaves of Dabsha cv. were rich with monoterpenes limonene, a-pinene and sesquiterpenes $\beta$-caryophyllene and a-gurjunene, while they presented as traces in Fagrikalan cv. Fagrikalan leaves produced mainly $\beta$-ocimene, a-selinene and $\beta$ selinene as their major constituents. These compounds represented $50.59 \%$ of the total Fagrikalan leaf essential oil contents compared with only $1.60 \%$ for Dabsha leaves.

\section{Toxicity assays.}

The results of toxicity assays (contact and spray toxicity) as represented in the tables (4 and 5), showed that, essential oil of Dabsha achieved significant high mortality percentages against $I$. seychellarum at the different concentrations $(100,1000,10000$ ppm). Essential oil of Dabsha and Fagrikalan leaves cvs. exhibited toxicity rate with concentration dependent. The highest toxicity rate of spray and contact assays was recorded for Dabsha mango leaves cv. (93.0\%) and (90.4\%) at the maximum conc. 10000 ppm, respectively, while, the Fagrikalan mango cv. caused $(36 \%)$ and $(14.73 \%)$ mortality at the same concentration. These findings were confirmed by Mesbah et. al., (2009) who showed that, the evaluated volatile oils exhibited a high efficiency against the mealybugs $I$. seychellarum and the highest reducing mealybugs was recorded with both camphor and rose volatile oils, followed by Dill, Peppermint and the least efficient was Clove volatile oil.

Limonene exhibited the highest nymphcidal activity against $I$. seychellarum followed by $a$-pinene and $\beta$-caryophyllene then terpinolene, respectively, while, the lowest value was recorded with $\beta$-ocimene. All four compounds (limonene, $\beta$ caryophyllene, a-pinene, and terpinolene) were toxic to I. seychellarum. The toxicity assays indicates the order of nymphcidal activities in the essential oils and their 
compounds as: Dabsha leaves essential oil $>$ limonene $>a$-pinene $>\beta$ caryophyllene $>$ terpinolene $>\beta$-ocimene $>$ Fagrikalan leaves essential oil.

Our results in agreement with the results of Monzer et. al., (2006), they found that total extract of Alphonso mango leaves are highly toxic to I. seychellarum, while, there were no significant in mortality percentages of $I$. seychellarum nymphs treated with all extracts of Sultani mango leaves and suggested that, $p$-cymene, camphene and limonene play an important role in resistance of Alphonso mango $\mathrm{cv}$. to $I$. seychellarum infestation. Also, Monzer et. al., (2013) suggested that, the combined action of a-pinene, $\beta$-pinene and limonene could be responsible of non-preference of Kilifia acuminate to leaves of Alphonso mango cv. Robert, (2005) showed that, limonene is an effective natural alternative to mineral oils that can be used to wet and kill wax-covered insects such as mealybugs, scales, and whiteflies. The toxicity of terpinolene was recognized for several stored product insect pests such as Sitophilus zeamais, Tribolium castaneum (Herbst) (Wang et. al., 2009).

\section{Repellency study:}

To our knowledge, no data are available on the repellent activity of Dabsha and Fagrikalan leaves essential oil and its pure major constituents against $I$. seychellarum nymphs. Fagrikalan and Dabsha leaves essential oil and its pure major constituents (limonene, a-pinene, terpinolene and $\beta$-caryophyllene from Dabsha leaves essential oil and $\beta$-ocimene of Fagrikalan leaves essential oil) were evaluated for their repellent activity against $I$. seychellarum nymphs.

The essential oils from Dabsha leaves and its pure major constituents exhibited good repellent activities against $I$. seychellarum nymphs at the given concentrations table (6). The repellent rate of Dabsha leaves cv. oil was clearly higher than Fagrikalan leaves oil at all concentrations. Data in table (6) also, showed that Dabsha cultivar essential oil possess the highest repellent activity against $I$. seychellarum, while, the lowest repellent activity was recorded with Fagrikalan leaves essential oil.

Our results indicated significant differences in repellence rates of the pure major constituents of Dabsha leaves essential oil against $I$. seychellarum, the highest rate recorded with limonene followed by a-pinene, $\beta$-caryophyllene then a-terpinolene, respectively, while, the lowest repellency rates was recorded with $\beta$-ocimene (the major constituent of Fagrikalan leaves essential oil) at the given concentrations. These findings confirmed the results of repellency of Dabsha and Fagrikalan leave essential oils. The decreasing order of repellency to nymphs was: Dabsha leaves essential oil > limonene $>$ a-pinene $>\beta$-caryophyllene $>$ terpinolene $>\beta$-ocimene $>$ Fagrikalan leaves essential oil. These results suggested that, Dabsha cv. oil and its pure major 
constituents have positive repellent effect on nymph of I. seychellarum. Finally, there was a significant attraction of $I$. seychellarum nymphs to Fagrikalan leaves essential oil and its pure major compound and repellence from Dabsha leaves essential oil and their pure major compounds. These results confirmed by Alwala et. al., (2010), they showed that, the essential oil of $M$. indica leaves showed a significant dose-dependent repellent effect on host-seeking female Anopheles gambiae. Many studies showed that pure major compounds of mango leaves essential oil have repellent activities against various insects of different families. Limonene is found to be repellent against several pest insects (Ibrahim et. al., 2001). Terpinolene has been shown to possess repellent activity against many insects (Benelli1 et. al., 2012). The high concentration of $\beta$-ocimene (36.80\%) and the presence of (Z) 3-Hexenol $(5.40 \%)$ in Fagrikalan leaves essential oil may be the reason of the attraction of $I$. seychellarum nymphs to Fagrikalan leaves essential oil. This conclusion was confirmed by Monzer et. al., (2006), they hypothesized that, $\beta$-ocimene play important role in the high susceptibility of Sultani mango cv. leaves to $I$. seychellarum infestation. Wei et. al., (2007), showed that, plants of pea leafminer, Liriomyza huidobrensis can effectively pull wasps, Opius dissitus, towards them by releasing a universally induced compound (Z)3-Hexenol and potentially keep these plants safe from parasitic assaults by leafminer pests, L. huidobrensis. This confirmed our results and supports our conclusion. The minor components like 3-carene, camphene, a-gurjunene and $\beta$ pinene may play an important role in repellent and insecticidal activities of Fagrikalan and Dabsha leaves essential oil to I. seychellarum. (see Nerio et. al., 2010).

\section{CONCLUSION}

Overall results indicated that the repellence and toxic effects of Dabsha leaves essential oil on $I$. seychellarum could be related to the high contents of limonene, $a$ pinene, $\beta$-caryophyllene and a-terpinolene. The presence of monoterpene $\beta$-ocimene with high concentration and (Z)3-Hexenol with slightly high concentration in essential oil of Fagrikalan leaves may be the reason for the high susceptibility of Fagrikalan mango $\mathrm{cv}$. to $I$. seychellarum infestation, 
Table 1. The collected scale insects that infest mango trees at Fisher mango orchards, Giza Governorate during 2011 and 2012 seasons.

\begin{tabular}{|c|c|c|c|c|c|c|}
\hline \multirow{2}{*}{ No. } & \multirow{2}{*}{ Insect scientific name } & \multirow{2}{*}{ Family } & \multicolumn{2}{|c|}{ Mean counts } & \multirow{2}{*}{ Total } & \multirow{2}{*}{$\%$} \\
\hline & & & 2011 & 2012 & & \\
\hline 1 & Icerya seychellarum (Westwod) & Monophlebidae & 40266 & 29189 & 69455 & 81.93 \\
\hline 2 & Lepidosaphes beckii (Newman) & Diaspididae & 5236 & 3048 & 8284 & 9.77 \\
\hline 3 & Kilifia acuminata (Signoret) & Coccidae & 2305 & 1765 & 4070 & 4.80 \\
\hline 4 & Hemiberlesia lataniae (Signoret) & Diaspididae & 927 & 685 & 1612 & 1.91 \\
\hline 5 & Ceroplastes floridensis (Comstock) & Coccidae & 268 & 163 & 431 & 0.51 \\
\hline 6 & Parlatoria oleae (Colvee) & Diaspididae & 254 & - & 254 & 0.23 \\
\hline 7 & Aulacaspis tubercularis (Newstead) & Diaspididae & 188 & - & 188 & 0.22 \\
\hline 8 & Aonidiella aurantii (Maskell) & Diaspididae & 60 & 98 & 158 & 0.19 \\
\hline 9 & Planococcus citri (Risso) & Pseudococcidae & 48 & 46 & 94 & 0.11 \\
\hline 10 & Icerya aegyptiaca (Douglas) & Monophlebidae & 89 & - & 89 & 0.10 \\
\hline 11 & Pulvinaria vitis (Linnaeus) & Coccidae & 71 & - & 71 & 0.09 \\
\hline 12 & Planococcus ficus (Signoret) & Pseudococcidae & - & 64 & 64 & 0.08 \\
\hline & & Total & 49712 & 35058 & 84770 & 100 \\
\hline
\end{tabular}




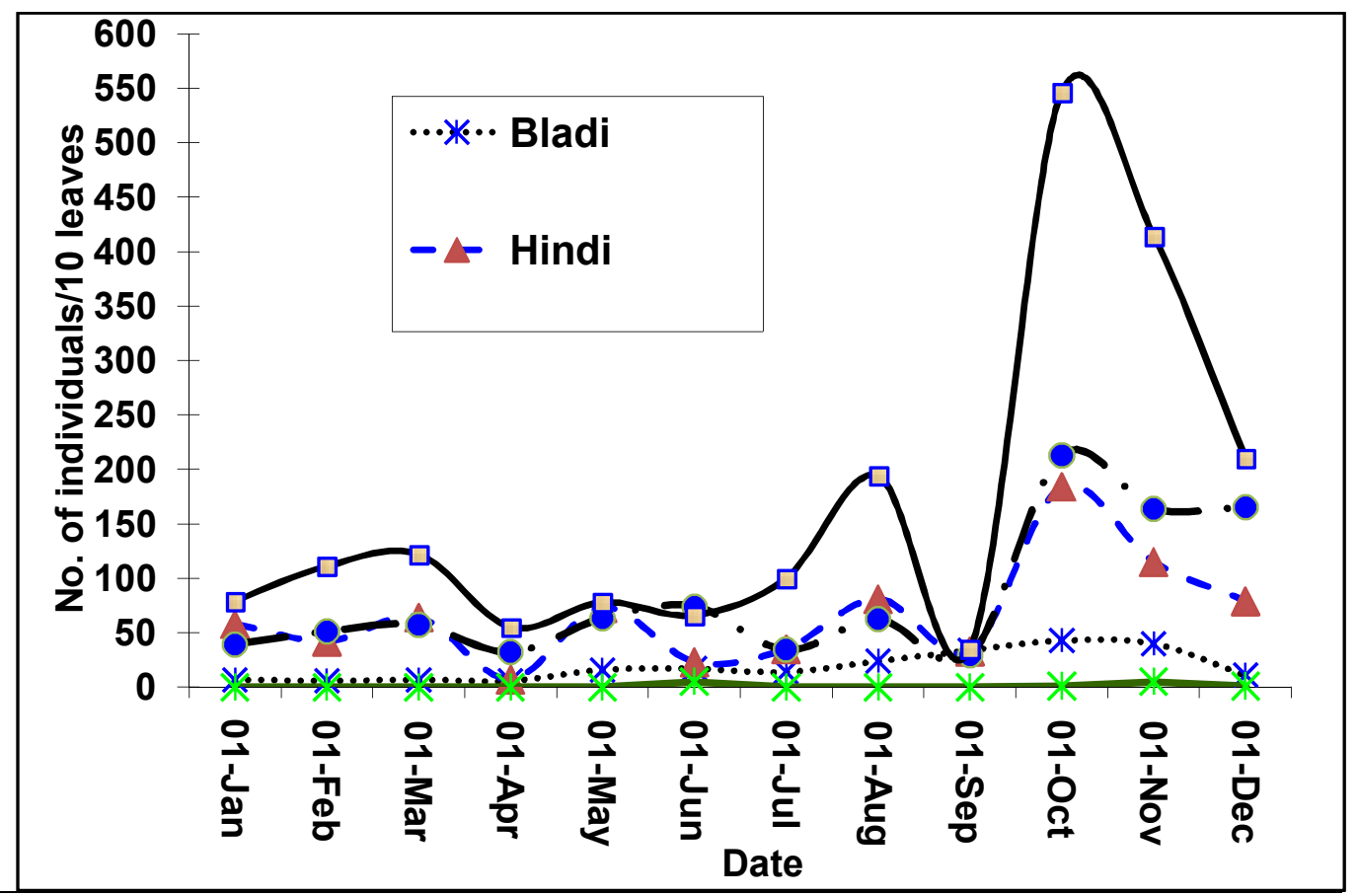

Fig. 1. Monthly mean counts of $I$. Seychellarum on five mango cultivars at Fisher mango orchards, Giza Governorate during season 2011.

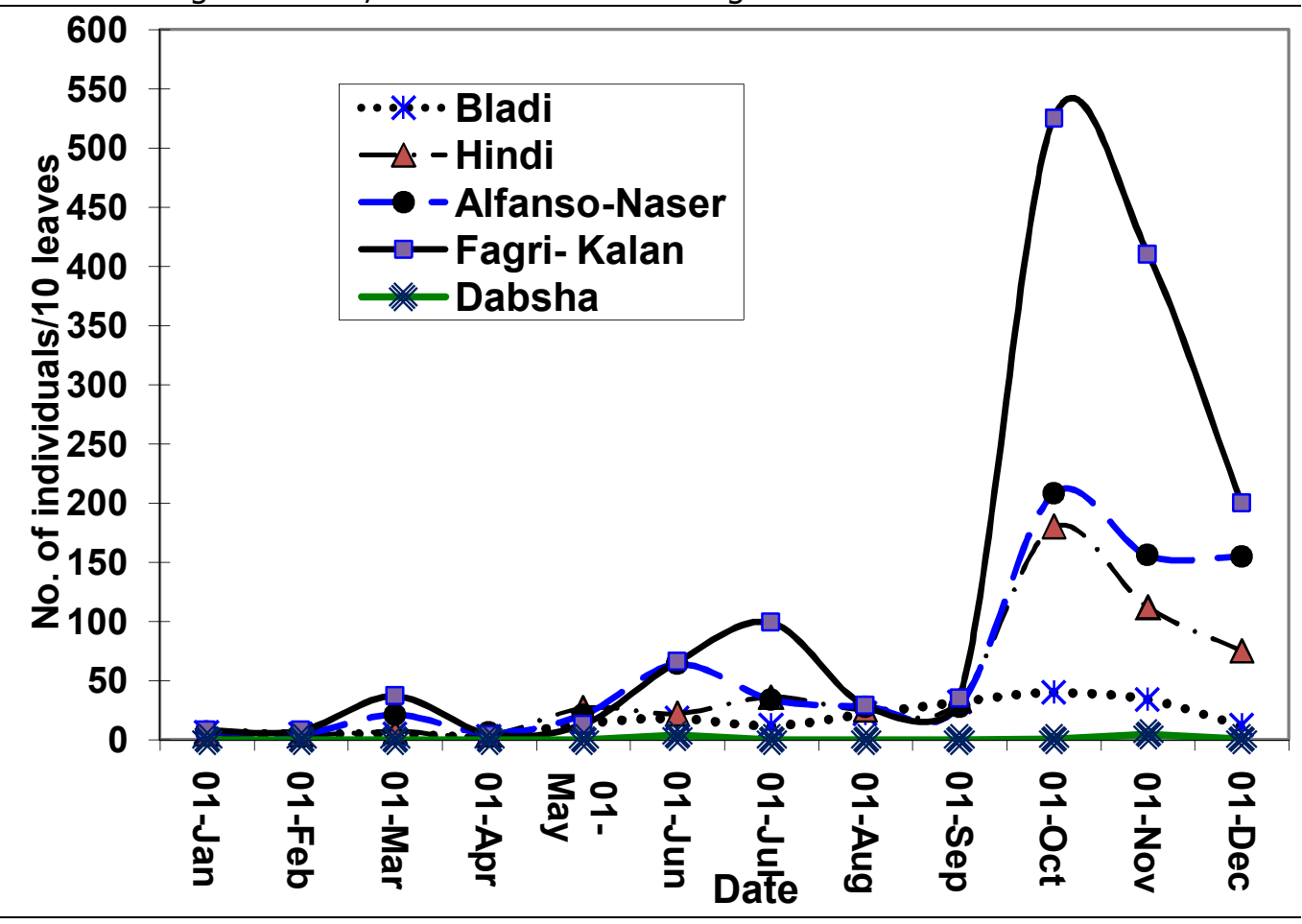

Fig. 2. Monthly mean counts of I. Seychellarum on five mango cultivars at Fisher mango orchards, Giza Governorate during season 2012. 
Table 2 . Monthly mean counts of $I$. Seychellarum on five mango cultivars at Fisher mango orch Governorate during 2011 and 2012 seasons.

\begin{tabular}{|c|c|c|c|c|c|c|c|c|c|c|c|c|}
\hline \multirow{3}{*}{$\begin{array}{l}\text { Date of } \\
\text { inspection }\end{array}$} & \multicolumn{12}{|c|}{ Mean number of individuals/ 10 leaves } \\
\hline & \multicolumn{2}{|c|}{ Fagri-Kalan } & \multicolumn{2}{|c|}{ Alfanso-Naser } & \multicolumn{2}{|c|}{ Hindi } & \multicolumn{2}{|c|}{ Baladi } & \multicolumn{2}{|c|}{ Dabsha } & \multicolumn{2}{|c|}{ Total } \\
\hline & 2011 & 2012 & 2011 & 2012 & 2011 & 2012 & 2011 & 2012 & 2011 & 2012 & 2011 & 2012 \\
\hline Jan & 79 & 8 & 39 & 7 & 58 & 5 & 7 & 6 & 0 & 0 & 183 & 26 \\
\hline Feb & 111 & 8 & 51 & 5 & 42 & 4 & 6 & 5 & 0 & 0 & 210 & 22 \\
\hline Mar & 122 & 37 & 57 & 21 & 64 & 7 & 7 & 5 & 0 & 0 & 250 & 70 \\
\hline Apr & 55 & 5 & 32 & 6 & 7 & 4 & 6 & 3 & 0 & 0 & 100 & 18 \\
\hline May & 78 & 13 & 63 & 21 & 73 & 27 & 16 & 14 & 0 & 0 & 230 & 75 \\
\hline Jun & 66 & 66 & 74 & 64 & 23 & 22 & 17 & 18 & 5 & 4 & 185 & 174 \\
\hline Jul & 100 & 99 & 34 & 34 & 35 & 36 & 14 & 12 & 0 & 0 & 183 & 181 \\
\hline Aug & 194 & 29 & 62 & 28 & 81 & 25 & 24 & 22 & 0 & 0 & 361 & 104 \\
\hline Sep & 35 & 35 & 29 & 28 & 33 & 33 & 34 & 32 & 0 & 0 & 131 & 128 \\
\hline Oct & 546 & 525 & 213 & 208 & 184 & 180 & 43 & 40 & 1 & 1 & 987 & 954 \\
\hline Nov & 414 & 410 & 164 & 156 & 115 & 112 & 40 & 34 & 5 & 5 & 738 & 717 \\
\hline Dec & 210 & 200 & 165 & 155 & 79 & 75 & 11 & 12 & 1 & 1 & 466 & 443 \\
\hline Total & 2010 & 1435 & 983 & 733 & 794 & 530 & 225 & 203 & 12 & 11 & 4024 & 2912 \\
\hline Avarage & 167 & 120 & 82 & 61 & 66 & 44 & 19 & 17 & 1 & 1 & 335 & 243 \\
\hline
\end{tabular}


Table 3. Chemical composition of the volatile oil from leaves of $M$. indica .

\begin{tabular}{|c|c|c|c|c|}
\hline \multirow[t]{2}{*}{ No. } & \multirow[t]{2}{*}{ Components } & \multirow{2}{*}{$\begin{array}{c}\text { Rt } \\
\text { (min) }\end{array}$} & \multicolumn{2}{|c|}{ Ratio (\%) } \\
\hline & & & $\left(\mathrm{L}_{1}\right)$ & (L2) \\
\hline & Monoterpene hydrocarbons & & & \\
\hline $1-$ & a-pinene & 7.13 & 0.20 & 14.39 \\
\hline $2-$ & camphene & 7.30 & 1.68 & 4.34 \\
\hline 3- & $\beta$-pinene & 7.47 & 1.56 & 3.19 \\
\hline 4- & $\beta$-myrcene & 8.23 & 3.10 & 1.20 \\
\hline $5-$ & 3 -carene & 9.14 & 0.60 & 5.26 \\
\hline 6- & $\beta$-ocimene & 10.06 & 36.80 & 1.15 \\
\hline 7- & p-Cymene & 10.56 & 2.10 & 2.34 \\
\hline 8- & Limonene & 10.85 & 0.10 & 15.30 \\
\hline \multirow[t]{3}{*}{ 9- } & a -Terpinolene & 11.45 & 0.66 & 7.70 \\
\hline & & & 46.70 & 54.87 \\
\hline & Oxygenated monoterpene & & & \\
\hline $10-$ & Eugenol & 20.14 & 1.10 & 3.45 \\
\hline $11-$ & Geranyl acetone & 21.12 & 1.27 & 1.34 \\
\hline \multirow[t]{3}{*}{$12-$} & Eugenyl acetate & 25.95 & ND & 0.56 \\
\hline & & & 2.37 & 5.35 \\
\hline & Sequiterpens hydrocarbons & & & \\
\hline 13- & $\beta$-Elemene & 22.07 & 4.50 & 0.25 \\
\hline 14- & $\beta$-Caryophyllene & 22.53 & ND & 9.16 \\
\hline 15- & a-Gurjunene & 22.75 & ND & 5.10 \\
\hline $16-$ & a -Caryophyllene & 22.85 & 1.70 & 0.59 \\
\hline 17- & a-Humulene & 23.18 & 1.20 & 0.14 \\
\hline $18-$ & $\beta$-chamigrene & 23.75 & 0.20 & 0.30 \\
\hline $19-$ & a-Selinene & 23.17 & 7.34 & 0.35 \\
\hline $20-$ & $\beta$-Selinene & 23.24 & 6.45 & 0.10 \\
\hline \multirow[t]{3}{*}{ 21- } & a--calacorene & 23.93 & 0.40 & 0.50 \\
\hline & & & 21.79 & 16.49 \\
\hline & Oxygenated sesquiterpenes & & & \\
\hline $22-$ & E-Nerolidol & 25.12 & 0.70 & 0.30 \\
\hline 23- & Spathullenol & 25.65 & 0.70 & 1.20 \\
\hline 24- & $\beta$-Caryophyllene oxide & 26.33 & 1.29 & 0.52 \\
\hline $25-$ & Viridiflorol & 26.78 & ND & 0.70 \\
\hline $26-$ & a-Humulene epioxid & 27.10 & 1.10 & 1.45 \\
\hline $27-$ & Cubenol & 28.35 & 1.65 & 0.36 \\
\hline \multirow[t]{3}{*}{$28-$} & a-Cadinol & 28.49 & 1.78 & 0.40 \\
\hline & & & 7.22 & 4.93 \\
\hline & Other compounds & & & \\
\hline $29-$ & (Z)3- Hexenol & 3.56 & 5.40 & 0.10 \\
\hline $30-$ & n Decan & 10.84 & 1.20 & 1.39 \\
\hline 31 & Palmitic acid & 31.44 & 1.23 & 1.98 \\
\hline $32-$ & Oleic acid & 32.21 & 1.13 & 1.67 \\
\hline 33- & Eicosane & 33.17 & 1.45 & 1.34 \\
\hline 34- & Tetracosane & 33.45 & 0.56 & 0.67 \\
\hline $35-$ & 1-methyl-7ethyl cyclopentane & 35.97 & 1.82 & 1.20 \\
\hline $36-$ & $1,2,3,4$ tetrahydro-1-naphthalene & 38.05 & 0.67 & 1.24 \\
\hline $37-$ & 3- methyl benzoic acid & 39.21 & 0.56 & 2.13 \\
\hline \multirow[t]{3}{*}{$38-$} & 1,2 dicarboxylic benzoic acid & 40.53 & 1.10 & 4.56 \\
\hline & & & 15.12 & 16.28 \\
\hline & Total identified & & 93.20 & 97.92 \\
\hline \multicolumn{2}{|c|}{ Rt : Retention time } & agrikelan & \multicolumn{2}{|c|}{ L2= Dabsha leaves } \\
\hline \multicolumn{2}{|c|}{ ND: not detected } & Trace & & \\
\hline
\end{tabular}


Table 4. Toxic effect (Spray assay) of Dabsha and Fagrikalan mango cvs. leaves essential oils and their major compounds against $I$. seychellarum nymph at different concentrations.

\begin{tabular}{|c|c|c|c|c|c|c|c|}
\hline $\begin{array}{c}\text { Mango cv. } \\
\text { and } \\
\text { compounds }\end{array}$ & $\begin{array}{c}\text { Dabsha } \\
\text { mango cv. }\end{array}$ & $\begin{array}{c}\text { Fagrikalan } \\
\text { mango cv. }\end{array}$ & Limonene & a-Pinene & $\begin{array}{c}\beta- \\
\text { Caryophyllene }\end{array}$ & $\begin{array}{c}\text { a- } \\
\text { Terpinolene }\end{array}$ & $\beta-$-Ocimene \\
\hline Conc. (ppm) & \multicolumn{7}{|c|}{ Corrected mortality (\%) } \\
\hline 100 & $\begin{array}{c}00.0 \pm 0.7 \\
8^{\mathrm{c}}\end{array}$ & $13.0 \pm 0.47^{\mathrm{c}}$ & $74.0 \pm 0.29^{\mathrm{c}}$ & $\begin{array}{c}50.0 \pm 1.76 \\
\mathrm{c}\end{array}$ & $53.0 \pm 0.89^{\mathrm{c}}$ & $69.9 \pm 0.95^{\mathrm{b}}$ & $29.0 \pm 0.35^{\mathrm{c}}$ \\
\hline 1000 & $\begin{array}{c}77.0 \pm 1.90 \\
\mathrm{~b}\end{array}$ & $22.0 \pm 0.21^{\mathrm{b}}$ & $85.0 \pm 1.42^{\mathrm{b}}$ & $\begin{array}{c}63.0 \pm \\
0.65^{\mathrm{b}}\end{array}$ & $81.0 \pm 0.35^{\mathrm{b}}$ & $81.1 \pm 0.15^{\mathrm{a}}$ & $40.0 \pm 0.53^{\mathrm{b}}$ \\
\hline 10,000 & $\begin{array}{c}93.0 \pm 0.51 \\
\mathrm{a}\end{array}$ & $36.0 \pm 0.55^{\mathrm{a}}$ & $91.0 \pm 0.66^{\mathrm{a}}$ & $\begin{array}{c}89.0 \pm 0.50 \\
\mathrm{a}\end{array}$ & $84.0 \pm 0.38^{\mathrm{a}}$ & $83.2 \pm 0.92^{\mathrm{a}}$ & $43.0 \pm 0.60^{\mathrm{a}}$ \\
\hline Control & 0.0 & 0.0 & 0.0 & 0.0 & 0.0 & 0.0 & 0.0 \\
\hline F value & $336.32^{* * *}$ & $162.05^{* * *}$ & $116.25^{* * *}$ & $564.2^{* * *}$ & $444.50^{* * *}$ & $168.51^{* * *}$ & $95.52^{* * *}$ \\
\hline LSD & 3.767 & 2.902 & 2.978 & 2.978 & 2.825 & 2.153 & 3.193 \\
\hline
\end{tabular}

Values (means \pm SD) followed by similar letter within the same column do not differ significantly $(P<0.05)$

Table 5. Toxic effect (Contact assay) of Dabsha and Fagrikalan mango cvs. leaves essential oils and their major compounds against $I$. seychellarum nymph at different concentrations.

\begin{tabular}{|c|c|c|c|c|c|c|c|}
\hline $\begin{array}{c}\text { Mango CV. } \\
\text { and } \\
\text { compounds }\end{array}$ & $\begin{array}{c}\text { Dabsha } \\
\text { mango cv. }\end{array}$ & $\begin{array}{l}\text { Fagrikalan } \\
\text { mango cv. }\end{array}$ & Limonene & a-Pinene & $\begin{array}{c}\beta- \\
\text { Caryophyllene }\end{array}$ & $\begin{array}{c}a- \\
\text { Terpinolene }\end{array}$ & $\begin{array}{c}\beta- \\
\text { Ocimene }\end{array}$ \\
\hline Conc. (ppm) & \multicolumn{7}{|c|}{ Corrected mortality (\%) } \\
\hline 100 & $\underset{c}{71.8 \pm 0.64}$ & $\begin{array}{c}11.80 \pm 0.4 \\
6^{\mathrm{a}}\end{array}$ & $71.22 \pm 1.5^{c}$ & $65.220 .39^{c}$ & $V \cdot . \bullet+ \pm 054^{c}$ & $77 . V \pm 0.32^{b}$ & $\begin{array}{c}23.7 \pm 0.36 \\
c\end{array}$ \\
\hline 1000 & $\begin{array}{c}83.6 \pm 0.25 \\
b\end{array}$ & $\begin{array}{c}12.91 \pm 0.2 \\
6^{\mathrm{a}}\end{array}$ & $82.3 \pm 1.10^{\mathrm{b}}$ & $\begin{array}{c}71.30 \pm 0.1 \\
5^{\mathrm{b}} \\
\end{array}$ & $\Lambda 1 . r \cdot \pm 0.60^{b}$ & Vo. $\Gamma \pm 0.89^{b}$ & $\underset{\mathrm{b}}{34.8 \pm 0.31}$ \\
\hline 10,000 & $\begin{array}{c}90.4 \pm 0.45 \\
a\end{array}$ & $\begin{array}{l}14.73 \pm 0.4 \\
5^{a}\end{array}$ & $\begin{array}{c}89.30 \pm 0.4 \\
5^{\mathrm{a}} \\
\end{array}$ & $\begin{array}{c}\Lambda 0 . Y \cdot \pm 0.4 \\
5^{\mathrm{a}}\end{array}$ & $\Lambda Y . r \cdot \pm 0.45^{a}$ & AI.r $\pm 0.45^{a}$ & $\begin{array}{c}39.0 \pm 0.45 \\
\mathrm{a}\end{array}$ \\
\hline Control & 0.0 & 0.0 & 0.0 & 0.0 & 0.0 & 0.0 & 0.0 \\
\hline$F$ value & $128.72 * * *$ & $1.72^{\text {ns }}$ & $69.13^{* * *}$ & $146.98 * * *$ & $126.01 * * *$ & $22.37 * *$ & $163.95^{* * *}$ \\
\hline LSD & 2.884 & 1.992 & 3.265 & 2.862 & 2.205 & 7.990 & 2.210 \\
\hline
\end{tabular}

Values (means \pm SD) followed by similar letter within the same column do not differ significantly $(P<0.05)$

Table 6. Repellency (\%) of Dabsha and Fagrikalan mango cvs. leaves essential oils and their major compounds against $I$. seychellarum at different concentrations.

\begin{tabular}{|c|c|c|c|c|c|c|c|}
\hline $\begin{array}{l}\text { Mango cV. } \\
\text { and } \\
\text { compounds }\end{array}$ & $\begin{array}{l}\text { Dabsha } \\
\text { mango cv. }\end{array}$ & $\begin{array}{l}\text { Fagrikalan } \\
\text { mango cv. }\end{array}$ & Limonene & a-Pinene & $\begin{array}{c}\beta- \\
\text { Caryophyllene }\end{array}$ & $\begin{array}{c}\mathrm{a}- \\
\text { Terpinolene }\end{array}$ & $\beta$-Ocimene \\
\hline Conc. (ppm) & \multicolumn{7}{|c|}{ Repellency (\%) } \\
\hline 100 & $\underset{b}{97.1 \pm 0.40}$ & $\underset{b}{13.7 \pm 0.35}$ & $\Lambda \wedge .\left\ulcorner \pm 0.10^{b}\right.$ & $\Lambda\left\ulcorner.\left\ulcorner \pm 0.11^{\mathrm{b}}\right.\right.$ & $\wedge 1 . \cdot \pm 0.15^{b}$ & Vo. $1 \cdot \pm 0.60^{b}$ & $\begin{array}{l}13.80 \pm 0.1 \\
1^{\mathrm{b}}\end{array}$ \\
\hline 1000 & $\underset{\mathrm{ab}}{98.0 \pm 0.58}$ & $\underset{\mathrm{b}}{14.8 \pm 0.25}$ & $\begin{array}{c}\wedge 9 . r^{\circ} \pm 0.2 \\
6^{b}\end{array}$ & $\begin{array}{c}\Lambda \wedge . r \cdot \pm 0.1 \\
0^{b}\end{array}$ & $\Lambda \Upsilon . r \cdot \pm 1.0^{b}$ & $\Lambda \cdot . \Sigma 0 \pm 0.16^{a}$ & $\begin{array}{l}14.91 \pm 0.0 \\
6^{\mathrm{b}}\end{array}$ \\
\hline 10,000 & $\begin{array}{c}99.4 \pm 0.62 \\
a\end{array}$ & $\begin{array}{l}23.0 \pm \\
0.20^{a}\end{array}$ & $\begin{array}{c}9 \varepsilon . Y \cdot \pm 0.5 \\
0^{a}\end{array}$ & $\begin{array}{c}\text { 91.r. } \cdot \pm 0.1 \\
0^{a}\end{array}$ & $\Lambda V . r \cdot \pm 0.21^{a}$ & $\Lambda \Gamma . \Sigma \pm 0.25^{a}$ & $\begin{array}{c}17 . V Y \pm 0.1 \\
2^{\mathrm{a}}\end{array}$ \\
\hline Control & 0.0 & 0.0 & 0.0 & 0.0 & 0.0 & 0.0 & 0.0 \\
\hline $\mathrm{F}$ value & $5.27^{*}$ & $\begin{array}{c}173.47^{* *} \\
*\end{array}$ & 8.74 & $12.07 * *$ & $11.04 * *$ & $20.24 * *$ & $8.10^{*}$ \\
\hline LSD & 1.93 & 1.226 & 3.240 & 3.908 & 8.571 & 2.580 & 1.485 \\
\hline
\end{tabular}

Values (means.$\pm \mathrm{SD}$ ) followed by similar letter within the same column do not differ significantly $(\mathrm{P}<0.05)$ 


\section{REFERENCES}

1. Abd-Elrahman, M.M., Salem, M. S., Moussa, S. M., Nour, M. E. and EL-said, M. I. 2007. Seasonal fluctuation of the seychelles fluted scale, Icerya seychellarum (Westwood) on four mango cultivars in Egypt. Egypt. J. Agnc. Res., 85 (1) : 77-88.

2. Adams, R.P. 2007. Identification of essential oil components by gas chromatography/ quadrupole mass spectroscopy; Allured: Carol Stream, IL, USA.

3. Alwala. J. O., Wanzala. W., Inyambukho, R. A., Osundwa. E. M. and Ndiege. O. 2010. Characterization and evaluation of repellent effect of essential oil of Mangifera indica L. on anopheles gambiae, from Kenya. Journal of Essential Oil Bearing Plants. 13(1): 85-96.

4. Assem, M.S. 1990. Survey and biological studies on some insects attacking certain ornamental plants. Ph.D. Thesis, Fac. Agric., Cairo Univ., Cairo, Egypt, 202p.

5. Benelli1, G., Flamini, G., Canale, A., Molfetta, I., Cioni, P. L. and Barbara. C. 2012. Repellence of Hyptis suaveolens whole essential oil and major constituents against adults of the granary weevil Sitophilus granaries. Bulletin of Insectology, 65 (2):177-183.

6. Costat. 2005. Version 6.311, Copyright(c), CoHort Software, 798 Lighthouse Ave. PMB 320, Monterey, CA, 93940, USA.

7. Dreistadt, S. H., Clark, J. K. and Flint, M. L. 1994. Pests of landscape trees and shrubs: An integrated pest management guide. Oakland: Univ. Calif. Div. Agric. Nat. Res., 3359.

8. El- Said. 2006. Studies on some Eco-physiological factors affecting resistance of five mango cultivars to the margarodid mealybug Icerya seychellarum (Westwood), Ph.D. Thesis, Department of Economic Entomolgy and Pesticides, Fac. Agric., Cairo Univ.120p. (50-55).

9. Engel, K. H. and Tressel, R. 1983. Studies on the volatile components of two mango varieties. J. Agr. Food Chem. 31:796-801.

10. Ibrahim, M. A., Kainulainen, P., Aflatuni, A., Tilikkala, K. and Holopainen, J. K. 2001. Insecticidal, repellent, antimicrobial activity and phytotoxicity of essential oils: With special reference to limonene and its suitability for control of insect pests. Agric. Food Sci. Finland, 10: 243-259.

11. Isman, M B. 2000. Plant essential oils for pest and disease management. Crop Protection 19 (8-10): 603-608.

12. Mesbah, H. A., Magda, Ael-K.., Mourad, A. K., Abdel-Razak, S. I., Weheda, M. L., Zaghloul, O. A. and Samar. E. A. 2009. Efficacy of five volatile oils and their 
mixtures against the mealybug, Icerya seychellarum (Westw.) infesting Sago palm, Cycas revoluta in Alexandria, Egypt. Commun Agric. Appl. Biol. Sci., 74(2):445-455.

13. Monzer, M. A., Salem, M. S., El-said M. I. and Melegi, A. 2006. Resistance of Alphonso mango-cultivar to the margarodid mealybug, Icerya seychellarum (Westwood) in relation to leaf quality: I. Leaf secondary metabolites. Egypt $J$. Agric. Res., 84 (1): 17-29.

14. Monzer, M. A., Srour, H. A. and Melegi, A. 2013. Isolation and identification of volatile substances in Alphonso mango leaves repellent to Kilifia acuminata (Signoret) (Hemiptera: Coccidae). New York Science Journal, 6 (12):84-91.

15. Nerio L. S., Olivero-Verbel J. and Stashenko E. 2010. Repellent activity of essential oils: a review.- Bioresource and Technology, 101: 372-378.

16. Pascual, J. M. and Robledo, A. 1997. Screening for anti-insect activity in Mediterranean plants. Industrial Crops Products, 8:183.

17. Pino, J. A., Mesa, J., Muoz, Y., Mart, M. P. and Marbot, R. 2005. Volatile components from mango (Mangifera indica L.) cultivars. J. Agric. Food Chem. 53: 2213-2223.

18. Robert, G. H. 2005. Limonene, a citrus extract, for control of mealybugs and scale insects. J. Econ. Entomol., 98(3):772-779.

19. Salem, M. I., El-Said, M. I., Melegi, A. and Monzer, M. A. 2007. Susceptibility of five mango cultivars to Seychelles fluted scale, Icerya seychellarum (West.) in relation to leaf quality: Leaf toughness and anatomical characteristics. Egypt. 1, Agric. Res., 85 (1):89-100.

20. Thurston, G.S., Yule, W.N. and Dunphy, G.B. 1994. Explination for the Iow susceptibility of Leptinotarsa decem/ineata to Steinernema carpocapsae. Biological Control 4: 53-58.

21. Wang, J. L., Li, Y. and Lei. C. L. 2009. Evaluation of monoterpenes for the control of Tribolium castaneum (Herbst) and Sitophilus zeamais Motschulsky- Natural Products Research, 23:1080-1088.

22. Wei, J., Wang, L., Zhu, J., Zhang, S. and Nandi, O. I. 2007. Plants attract parasitic wasps to defend themselves against insect pests by releasing (Z) 3-Hexenol. PLOS ONE 2(9): e852. doi:10.1371/journal.pone.0000852. 


\title{
تفسير ظاهرة قابلية إصابة بعض أصناف المانجو
}

\section{Icerya seychellarum بالبق الدقيقي}

يهدف هذا البحث إلي إجراء حصر للحشرات القشرية والبق الدقيقي في مـز ارع المــانجو

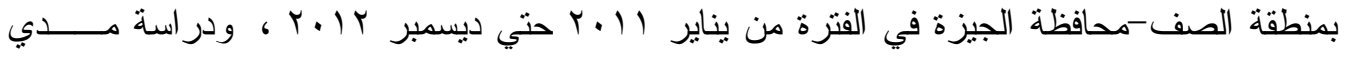

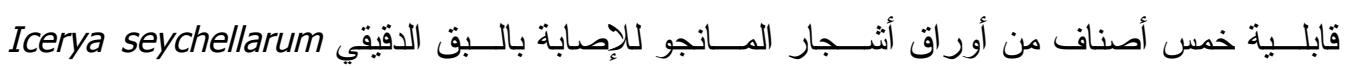

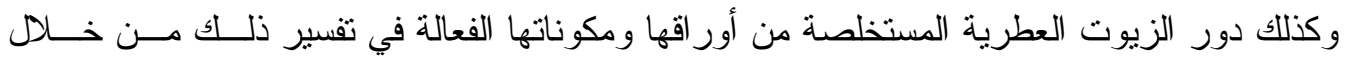

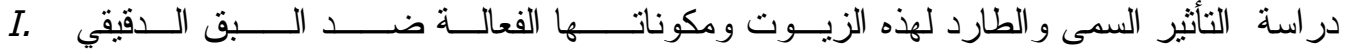
seychellarum وقد أظهرت النتائج أن r ا نوع من الحشرات القشرية و البق الدقيقي و التي تتتـــي

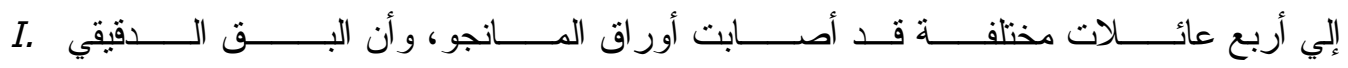

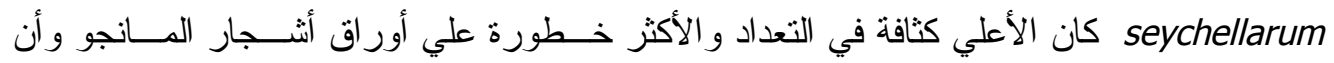
معسدل التعداد السنوي لحشرة I. seychellarum اختلفت بشكل ملحوظ في قابلية الأصناف الخمسة للإصابة، فوجد أن صنف الفجرى كلان هو اعلي الأصناف إصابة ثم يليه صنف ألفونسو ناصر ثم

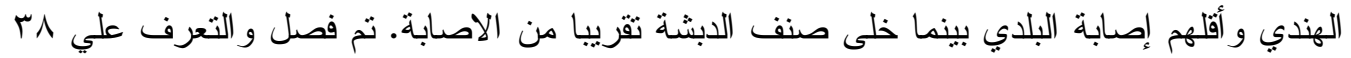

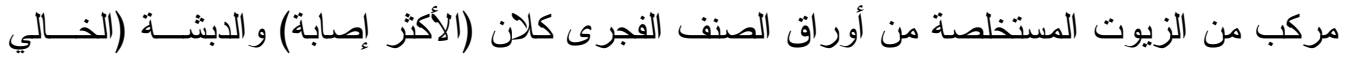

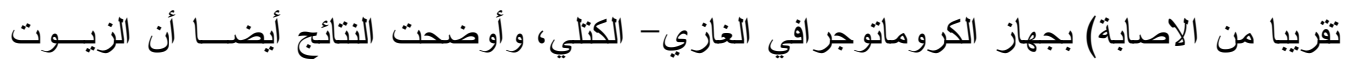
I. العطرية ومركباتها الفعالة لها دور كبير في تباين قابلية أصناف المانجو للإصـابة بــالبق الــدقيقي

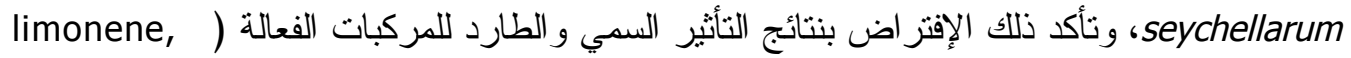
a-pinene and $\beta$-caryophyllene 